\title{
A metabolic map of hematopoietic stem cells
}

\author{
Michalis Agathocleous ${ }^{*}$, Zeping Hu, Sean Morrison \\ From Metabolism, Diet and Disease 2014: Cancer and metabolism \\ Washington DC, USA. 28-30 May 2014
}

\section{Background}

A general problem in biology is whether different types of cells in the same tissue are metabolically different from each other, and whether such differences are important for cellular function. Experiments that can comprehensively measure the cellular metabolome typically require millions of cultured cells and cannot be used with small numbers of rare cells freshly isolated from tissues. In particular, hematopoietic stem cells (HSCs), the blood forming stem cells of the bone marrow, have been intensively studied for decades but their metabolic composition is largely unknown.

\section{Results}

We have developed a method to measure metabolites in small numbers of HSCs. The HSC isolation and mass spectrometry methods have been optimized for maintenance of the metabolome during purification, sensitivity and robustness. About 50 metabolites can be quantified from 10,000 HSCs, covering a wide spectrum of the cellular metabolome. Several metabolic differences exist between HSCs and other bone marrow cells, including restricted progenitors. I am investigating the role of these metabolic adaptations in HSCs.

\section{Conclusion}

The ability to profile the metabolome of rare cells isolated directly from tissues opens the possibility to metabolically compare stem cells to other purified populations of cells at different stages of differentiation, to test the metabolic consequences of physiological challenges like aging on specific populations of cells, and to test whether other rare cells, like subpopulations of cancer cells from the same tumor, are metabolically distinctive.

Children's Research Institute, UT Southwestern Medical Center, Dallas, TX, USA

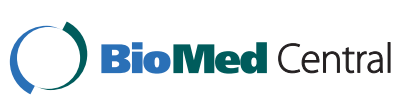

Published: 28 May 2014

doi:10.1186/2049-3002-2-S1-P1

Cite this article as: Agathocleous et al:: A metabolic map of

hematopoietic stem cells. Cancer \& Metabolism 2014 2(Suppl 1):P1.
Submit your next manuscript to BioMed Central and take full advantage of:

- Convenient online submission

- Thorough peer review

- No space constraints or color figure charges

- Immediate publication on acceptance

- Inclusion in PubMed, CAS, Scopus and Google Scholar

- Research which is freely available for redistribution
() Biomed Central 